\title{
Perbedaan kualitas radiograf periapikal antara film konvensional dan film instan di Instalasi Radiologi FKG Universitas Brawijaya Malang
}

\author{
Farihah Septinal*, Robbyn Reyvaldo²
}

\begin{abstract}
Objectives: This study is aimed to look at the distribution of the quality of periapical radiographs produced by students using conventional films and instant films at the Faculty of Dentistry Universitas Brawijaya Radiology Installation.

Material and Methods: The method used in this research is analytic descriptive with cross sectional sampling method. The research datas were primary data with a total of 20 periapical radiographs from each method. Data was analyzed by Spearman test in SPSS software.

Results: Data were analysed using the Spearman rho correlation test which showed the results of $\rho=$ 0,5 . The results of periapical radiographs using conventional films as much as $65 \%$ were very good, $25 \%$ were good, and $10 \%$ were not acceptable. The results of periapical radiographs using instant film were $70 \%$ good, $15 \%$ very good, and $15 \%$ were not acceptable.

Conclusion: There is no difference in the quality of the results of conventional periapical radiographs and instant films in the Radiology Installation of the Faculty of Dentistry Universitas Brawijaya Malang.

${ }^{1}$ Departemen Radiologi Kedokteran Gigi, Fakultas Kedokteran Gigi, Universitas Brawijaya, Malang, Indonesia, 65145

${ }^{2}$ Program Studi Sarjana Kedokteran Gigi, Fakultas Kedokteran Gigi, Universitas Brawijaya, Malang, Indonesia, 65145

${ }^{*}$ Correspondence to:

Farihah Septina

$\bowtie$ farihahseptina@gmail.com

Received on: October 2019 Revised on: December 2020 Accepted on: April 2020

Keywords: Periapical radiograph, conventional film, instant film, radiograph quality

Cite this article: Septina F, Reyvaldo R. Perbedaan kualitas radiograf periapikal antara film konvensional dan film instan di Instalasi Radiologi FKG Universitas Brawijaya Malang. Jurnal Radiologi Dentomaksilofasial Indonesia 2020;4(1)45-9. https://doi.org/10.32793/jrdi.v4i1.447

\section{PENDAHULUAN}

Pemeriksaan radiograf telah menjadi salah satu alat bantu diagnosis utama di bidang kedokteran gigi untuk menentukan keadaan penyakit dan merencanakan perawatan yang tepat. ${ }^{1}$ Radiograf memegang peranan penting dalam menegakkan diagnosis sebelum perawatan dan pengobatan, dalam masa perawatan serta untuk evaluasi hasil perawatan, khususnya dalam perawatan yang membutuhkan radiograf, untuk menunjang peranan tersebut maka diperlukan radiograf dengan teknik yang tepat. ${ }^{2}$ Teknik radiograf yang digunakan dalam bidang kedokteran gigi dapat dibagi menjadi dua yaitu teknik intraoral dan ekstraoral. Pada teknik intraoral, film diletakkan di dalam mulut pasien, yang terdiri dari teknik radiograf periapikal, bitewing dan oklusal, sedangkan pada teknik radiograf ekstraoral, film diletakkan di luar mulut pasien, salah satunya adalah teknik panoramik, macam lainnya adalah lateral foto, sefalometri dan lain-lain. ${ }^{3}$

Radiograf periapikal adalah radiograf intraoral yang menunjukkan mahkota dan akar dari satu atau beberapa gigi termasuk jaringan periapeks dan mempunyai manfaat diagnostik dalam terapi endodontik dan dalam mendeteksi patologi periapeks. ${ }^{4}$ Tujuan radiograf periapikal adalah untuk merekam seluruh gigi dan tulang pendukung, dan digunakan untuk evaluasi karies dan kehilangan tulang periodontal, serta membantu dalam diagnosis dan perawatan. Penelitian yang dilakukan oleh Ishaq menyebutkan bahwa $73.33 \%$ dokter gigi di Kabupaten Maros menggunakan radiograf periapikal sebagai pemeriksaan penunjang perawatan endodontik. $^{5}$

Faktor yang memengaruhi kualitas radiograf dalam pembuatannya antara lain: peralatan sinar $X$, film yang digunakan, processing, pasien, operator, dan teknik pembuatan radiograf yang dilakukan. ${ }^{3}$ Penelitian oleh Masserat et al. menyebutkan bahwa terdapat 296 kegagalan yang terdiri dari 281 kegagalan karena kesalahan teknis dan 15 kegagalan karena kesalahan pengolahan. Kegagalan karena kesalahan teknis antara lain pemanjangan, pemendekan, sudut horizontal yang salah, peletakan film yang salah, terpotongnya obyek karena kerucut, terpotongnya bagian akar, radiograf terlalu gelap, radiograf terlalu terang, objek kabur atau buram, pengambilan gambar lebih dari satu kali, film terbalik dalam peletakan. ${ }^{6}$

Film pada radiograf periapikal ada dua, yaitu film konvensional dan film instan. Keduanya membutuhkan penggunaan teknik yang hati-hati sebagai tindakan pencegahan agar kesalahannya minimal dan nilai diagnostik serta interpretatif yang maksimal. ${ }^{1}$ Perbedaan film konvensional dan film instan terletak pada processingnya. Untuk film 
konvensional processing dilakukan di dalam kamar gelap dan menggunakan larutan developer dan fixer sebagai larutan processing, untuk film instan processing dilakukan tanpa kamar gelap tetapi menggunaan larutan processing yang diinjeksikan ke dalam film packing yang kemudian dilakukan agitasi untuk meratakan larutan. Penggunaan radiograf untuk menunjang diagnosis pada suatu kasus dalam kedokteran gigi memiliki peranan penting, sehingga perlu dipertimbangkan penggunaan film konvensional atau film instan. Penggunaan film instan lebih unggul dalam tahapan processing, karena pada standard operating procedure dapat meminimalisir kesalahan tahapan processing dan kecepatan serta kepraktisan film.

Sebelum melakukan analisis atau interpretasi suatu radiograf, kualitas dari radiograf tersebut harus diperiksa terlebih dahulu karena kualitas yang tidak adekuat akan membatasi informasi penting yang didapat dari pencitraan diagnostik, misalnya radiograf tersebut mengalami distorsi atau elongasi. $^{3}$ Berdasarkan penelitian yang telah dilakukan dikatakan bahwa, terdapat 4 kesalahan utama yang ditemukan yaitu: kesalahan penempatan film $(35,4 \%)$, cone cutting $(18,2 \%)$, kesalahan angulasi horizontal (16,6\%), dan kesalahan angulasi vertikal $(14,4 \%)$.

Penelitian terhadap teknik processing masih jarang dilakukan, akan tetapi persentase kesalahan pada proses ini cukup memberikan pengaruh yang besar. ${ }^{7}$ Selain itu permasalahan di Instalas Radiologi Fakultas Kedokteran Gigi Universitas Brawijaya (FKG UB) didominasi oleh banyaknya keluhan dari instruktur yang meyatakan bahwa hasil radiograf yang menggunakan film instan memiliki kualitas yang kurang baik jika dibandingkan dengan film konvensional. Penelitian ini bertujuan untuk melihat distribusi kualitas radiograf periapikal yang dihasilkan mahasiswa dengan menggunakan film konvensional dan film instan di Instalasi Radiologi FKG UB.

\section{BAHAN DAN METODE}

Jenis penelitian ini adalah deskripsi analitik observasional dengan pendekatan cross sectional. Populasi penelitian ini adalah seluruh radiograf periapikal yang dibuat oleh mahasiswa profesi radiologi dengan pembagian berikut, dalam satu bulan dibagi menjadi dua kelompok yang tiap stase terdiri dari 5 mahasiswa, tiap mahasiswa kemudian melakukan 2 foto radiograf sehingga jumlah populasi 20 radiograf. Sampel ditetapkan berdasarkan teknik total sampling. Instrumen penelitian yang digunakan adalah lembar observasi yang dibuat oleh peneliti. Waktu penelitian pada bulan April-Mei 2019 bertempat di Instalasi Radiologi Fakultas Kedokteran Gigi Universitas Brawijaya. Analisis data dilakukan dengan uji beda. Penelitian ini telah dilakukan uji Etik di Komisi Etik Penelitian Kesehatan Fakultas Kedokteran Universitas Brawijaya dengan no 139 / EC / KEPK-S1 - FKG / 04 / 2019.

Alat dan bahan penelitian ini meliputi, 1) Alat tulis, 2) Cheklist processing film konvensional dan film instan, 3) Penjepit film, 4) Film konvensional periapikal (merk Kodak), 5) Film instan periapikal (merk Hanshin); Larutan DQE dan hardening merk Hanshin, 6) Mounting film periapikal, 7) Larutan processing yaitu developer (merk Fuji Film) ; larutan fixer (merk Fuji Film); Tangki berisi air , 8) Unit radiologi periapikal (merk Endos ACP dengan kecepatan 50-70 kVp), 9) Kamar gelap; Timer, Viewer; Syringe $5 \mathrm{ml}$; Alat pendingin ruangan (Air Conditioner).

Langkah penelitian ini adalah sebagai berikut, peneliti melakukan informed consent pasien, pasien dilakukan eksposur menggunakan film konvensional, pasien dilakukan eksposur menggunakan film instan, selanjutnya mengamati tahapan processing radiograf periapikal konvensional pada film konvensional, dimana obsevasi dilakukan dalam dua waktu berbeda dan pada setiap bulan diambil 10 sampel, kemudian mengamati tahapan processing radiograf periapikal menggunakan DQE yang disuntikkan ke film instan dan kemudian direndam larutan hardening, dimana obsevasi dilakukan dalam dua waktu berbeda dan pada setiap bulan diambil 10 sampel, dan terakhir pengamat mengamati radiograf yang telah dilakukan tahapan processing pada viewer, dan memberikan nilai sesuai kelompok.

\section{HASIL}

Data dari hasil pengelompokan kualitas radiograf periapikal film konvensional dapat dilihat pada Tabel 1 dan film instan pada Tabel 2 . Berdasarkan tampilan data pada tabel terlihat bahwa dari Tabel 1 didapatkan hasil radiograf periapikal dengan film konvensional sebanyak $65 \%$ sangat baik, $25 \%$ baik, dan $10 \%$ tidak dapat diterima, sedangkan pada Tabel 2 didapatkan hasil radiograf periapikal dengan film instan sebanyak $70 \%$ baik, $15 \%$ sangat baik, dan $15 \%$ tidak dapat diterima. Analisis perbedaan kualitas antara

Tabel 1. Hasil pengelompokkan kualitas radiograf periapikal film konvensional

\begin{tabular}{lcc}
\hline Skor & Frekuensi $(\mathbf{n})$ & Persentase (\%) \\
\hline Tidak dapat diterima (skor = 1) & 2 & 10 \\
\hline Baik (skor = 2) & 5 & 25 \\
\hline Sangat baik (skor = 3) & 13 & 65 \\
\hline Total & 20 & 100 \\
\hline
\end{tabular}


Tabel 2. Hasil pengelompokkan kualitas radiograf periapikal film konvensional

\begin{tabular}{lcc}
\hline Skor & Frekuensi (n) & Persentase (\%) \\
\hline Tidak dapat diterima (skor = 1) & 3 & 15 \\
\hline Baik (skor = 2) & 14 & 70 \\
\hline Sangat baik (skor $=3$ ) & 3 & 15 \\
\hline Total & 20 & 100 \\
\hline
\end{tabular}

Tabel 3. Hasil uji beda kualitas antara radiograf periapikal film konvensional dan film instan

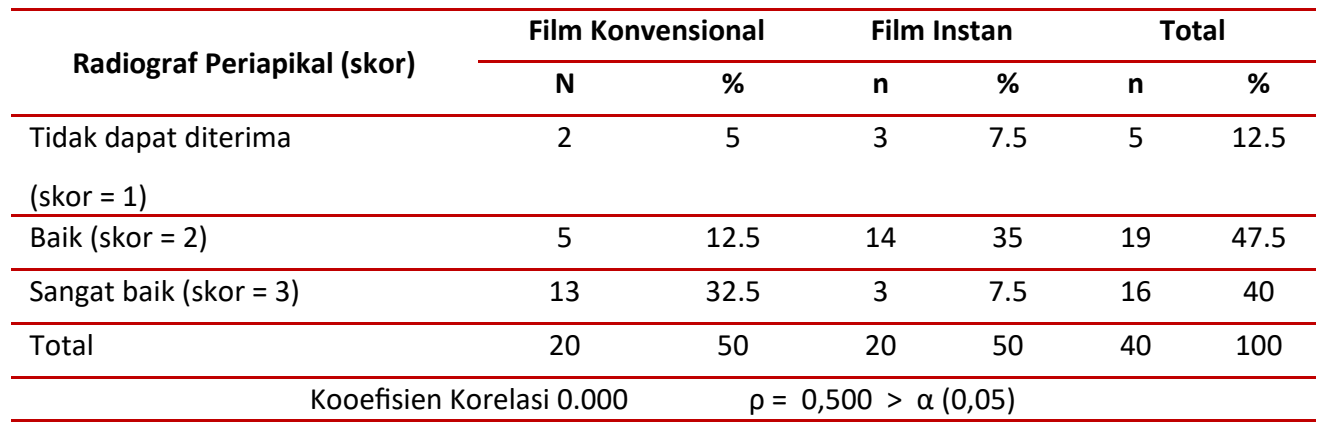

radiograf periapikal film konvensional dan film instan disajikan dalam Tabel 3. Dari Tabel 3 tersebut didapatkan hasil bahwa sebagian besar radiograf periapikal film konvensional sebanyak $32.5 \%$ sangat baik dan radiograf periapikal film instan sebanyak $35 \%$ baik.

Berdasarkan hasil uji rho Spearman didapatkan hasil $\rho=0,500$, berarti $\rho>\alpha(0,05)$ sehingga $H_{1}$ ditolak yang artinya tidak ada perbedaan kualitas hasil radiograf periapikal film konvensional dan film instan pada mahasiswa profesi radiologi Fakultas Kedokteran Gigi Universitas Brawijaya Malang. Nilai koefisien korelasi 0.000 artinya nilai hubungan sangat rendah dengan arah hubungan positif.

\section{DISKUSI}

Hasil radiograf periapikal dengan film konvensional pada Tabel 1 sebanyak 65\% sangat baik, 25\% baik, dan 10\% tidak dapat diterima. Menurut Whaites dan Drage, faktor penyebab kegagalan pembuatan radiograf yang dilakukan saat processing secara konvensional, antara lain: waktu perendaman film dalam developer yang terlalu panjang atau terlalu pendek, konsentrasi dan suhu developer yang terlalu tinggi, larutan fixer yang sudah terlalu sering dipakai, waktu perendaman film dalam fixer yang inadekuat, operator memegang film menggunakan tangan dengan tidak hati-hati saat di ruang gelap, dan film terkontaminasi oleh cairan kimia lain. ${ }^{3}$

Hasil penelitian yang dilakukan oleh Peker dan Alkurt (2009) didapatkan hasil bahwa kesalahan pada processing radiograf dengan persentase yang lebih sedikit $(2,77 \%)$ dan keberhasilan pada processing radiograf dengan persentase yang lebih banyak $(97,23 \%)$, meskipun begitu kesalahan yang sedikit tersebut berpengaruh besar terhadap hasil radiograf. Pada penelitian ini ternyata terlihat bahwa faktor yang menyebabkan kegagalan pada proses processing fim terletak pada human error (kesalahan manusia), dimana operator melakukan minimalisasi perendaman film pada larutan fixer dan larutan developer menjadi 30 detik menggunakan timer, ditambah dengan pengaturan suhu kamar yang diatur. Pada tahap processing operator juga memegang film menggunakan tangan yang dilakukan secara hati-hati, dan juga dijaga agar tidak terkontaminasi oleh cairan kimia lain, serta penggunaan larutan fixer dan developer baru pada setiap processing film. $^{9}$

Kelebihan film konvensional adalah harganya yang relatif murah, film lebih mudah ditempatkan di dalam rongga mulut karena sifatnya yang fleksibel dan mudah dibengkokkan. Kemungkinan penyebab kelebihan film konvensional yang didapat dalam penelitian ini, film konvensional lebih mudah didapat dari pada film instan, gambaran hasil film lebih baik dalam aspek kontras, detail, dan ketajaman meski gambaran lebih gelap, operator bisa mengontrol hasil film dengan lama waktu perendaman film pada larutan developer dan larutan fixer, ukuran panjang packing film tidak lebih panjang dari packing film instan sehingga meminimalisir rasa tidak nyaman pada pasien, mahasiswa sudah lebih terlatih menggunakan radiograf konvensional. ${ }^{9}$

Film konvensional yang peneliti dapatkan sebanyak $65 \%$ hasil radiograf periapikal sangat baik. Dengan hasil yang peneliti dapatkan, terdapat 13 sampel kualitas hasil film konvensional sangat baik dengan rincian keterangan dari pengamat: kontras, detail, ketajaman yang didapatkan sangat baik melebihi hasil film konvensional lain dan film instan. Hal ini dapat disebabkan karena lengkapnya panduan standard operating procedure pada tahap processing, sehingga kesalahan prosedur dapat 
ditekan. Pada saat penelitian suhu larutan developer sudah tepat. Suhu larutan developer yang terdapat di Instalasi Radiologi Fakultas Kedokteran Gigi Universitas Brawijaya berkisar antara $21^{\circ} \mathrm{C}$ hingga $22^{\circ} \mathrm{C}$ sudah sesuai dengan suhu yang dianjurkan, suhu larutan developer yang dianjurkan yaitu $20^{\circ} \mathrm{C}$ hingga $26^{\circ} \mathrm{C}$. Suhu developer digunakan untuk menentukan durasi perendaman film yang tepat pada processing manual. Semakin tinggi suhu developer, maka semakin berkurang durasi perendaman yang dibutuhkan, begitu pula sebaliknya. Developer dengan suhu lebih rendah dibandingkan yang dianjurkan akan menyebabkan aktivitas kimiawi pada developer berjalan lebih lambat, sehingga radiograf dapat mengalam underdevelopment. ${ }^{10,11}$

Film konvensional yang peneliti dapatkan sebanyak $25 \%$ hasil radiograf periapikal baik dengan kontras, detail, ketajaman yang didapatkan lebih baik dari film instan. Jika dibandingkan dengan 13 film atau $65 \%$ film konvensional sebelumnya dengan kualitas hasil sangat baik, 5 film atau 25\% film ini kualitasnya tidak lebih baik, berdasarkan hasil penelitian, 5 film radiograf periapikal tersebut hasil lebih hitam (fogging). Fogging merupakan peningkatan densitas pada film yang bisa disebabkan oleh penyimpanan film yang tidak tepat, kesalahan yang terjadi di kamar gelap (dark room), dan kesalahan selama tahapan processing. Ketika film terekspos cahaya lampu pengaman dengan jarak yang tidak adekuat, maka seluruh kristal perak halida yang tidak terekspos akan menjadi terekspos, sehingga film akan mengandung $100 \%$ kristal perak halida yang terekspos. Seluruh kristal perak halida akan berubah menjadi kristal perak metalik hitam setelah tahapan development sehingga hasil akhir radiograf akan berwarna hitam. ${ }^{12}$

Film konvensional yang peneliti dapatkan, sebanyak $10 \%$ hasil radiograf periapikal dengan hasil tidak diterima, dengan rincian 2 gambaran film konvensional terlalu gelap sehingga hasil tidak diterima. Hal tersebut ada hubungannya dengan tabel standar operating procedure tahapan processing. Pada waktu processing film, penelit menemukan waktu perendaman film pada larutan developer lebih dari 30 detik. Pemrosesan film pada suhu yang lebih tinggi atau lebih rendah dan dengan durasi yang lebih cepat atau lambat dapat menurunkan kontras dari film. Suhu larutan developer yang terdapat di Instalasi Radiolog Fakultas Kedokteran Gigi Universitas Brawijaya berkisar antara $21^{\circ} \mathrm{C}$ hingga $22^{\circ} \mathrm{C}$ hal tersebut sudah tepat. Sesuai dengan suhu larutan developer yang dianjurkan yaitu $20^{\circ} \mathrm{C}$ hingga $26^{\circ} \mathrm{C}$. Suhu developer yang digunakan, juga menentukan durasi perendaman film yang tepat pada processing, pada penelitian ini durasi perendaman film pada larutan developer ditentukan selama 30 detik. Kedua hal tersebutlah yang menghasilkan film dengan kontras, detail dan ketajaman yang baik. Processing merupakan salah satu faktor yang memengaruhi kontras dari suatu radiograf. Salah satu kandungan pada larutan developer adalah hydroquinone, yang berfungsi membangun kontras pada radiograf
Processing film yang salah pada tahapan development yang kurang atau berlebihan, dapat mengurangi kontras pada radiograf. ${ }^{10}$

Hasil radiograf periapikal dengan film instan sebanyak $70 \%$ baik, $15 \%$ sangat baik, dan $15 \%$ tidak dapat diterima. Film instan adalah film dengan suatu cara atau proses untuk mendapatkan gambar permanen dari foto rontgen dengan memakai zat atau cairan kimia tanpa menggunakan kamar gelap. Keunggulan dari film instan adalah mengurangi kesalahan tahap processing dan kecepatan serta kepraktisan film serta tidak memerlukan kamar gelap, serta kualitas yang dihasilkan dapat terjaga karena tidak memakai larutan processing yang digunakan berulang.

Dari hasil penilaian pada radiograf periapikal dengan film instan, sebanyak $15 \%$ radiograf periapikal ditemukan dengan hasil yang sangat baik. Dengan hasil yang peneliti dapatkan, terdapat 3 sampel kualitas hasil film instan sangat baik dengan rincian keterangan keseluruhan interpretasi dari pengamat: kontras, detail, ketajaman yang sangat baik melebihi hasil film instan lain dan didapat gambaran lebih terang dari film konvensional dan hasil sangat baik, sehingga dapat diinterpretasi. Hal tersebut ada hubungannya dengan tabel standar operating procedure pada tahapan processing, karena keseluruhan tahapan standar operating procedure yang sudah dilakukan dengan benar dan tepat terutama dalam processing film yaitu waktu agitasi dan pengeluaran film dari packing tepat 30 detik. Film instan lebih baik karena kepraktisannya, pada tahap processing membutuhkan waktu yang pendek dan tidak memerlukan kamar gelap sehingga meminimalisir kesalahan pada tahap processing. Sesuai dengan kesimpulan perbandingan dari standar operating procedur antara film konvensional dengan film instan, keunggulan dari film instan adalah mengurangi kesalahan tahap processing dan kecepatan, serta kepraktisan film serta tidak memerlukan kamar gelap.

Hasil radiograf periapikal dengan film instan, sebanyak $70 \%$ radiograf periapikal dengan hasil baik. Dengan hasil yang peneliti dapatkan, terdapat 14 sampel kualitas hasil film instan baik dengan rincian keterangan keseluruhan interpretasi dari pengamat: kontras, detail, ketajaman yang didapatkan baik dengan gambaran lebih terang dari film konvensional. Hal tersebut ada hubungannya dengan tabel standar operating procedure tahapan processing, keseluruhan tahapan processing sudah dilakukan dengan benar. Waktu agitasi dilakukan selama 30 detik, tetapi membutuhkan waktu pengeluaran film dari packing kurang lebih dari 5 detik sehingga peneliti menduga hal tersebut yang membuat gambaran hasil kurang maksimal. Sesuai penelitian Suryantoro pada tahun 2007, bahwa film instan Hanshin D-speed menghasilkan detail yang baik pada interdental gigi. ${ }^{13}$

Hasil radiograf periapikal dengan film instan, sebanyak $15 \%$ hasil radiograf periapikal tidak dapat diterima. Dengan hasil yang peneliti dapatkan, terdapat 3 sampel kualitas hasil film instan tidak dapat diterima dengan rincian keterangan dari 
pengamat: kontras, detail, ketajaman yang didapatkan tidak dapat diterima dengan gambaran nampak lebih terang dari 14 film instan atau $70 \%$ film yang kualitas hasilnya baik dan 3 film atau 15\% film yang kualitas hasilnya sangat baik, pada tabel tingkatan kualitas subyektif radiograf oleh Whites dan Drage, kualitas yang tidak dapat diterima salah satunya adalah kegagalan pada tahap processing, sehingga dapat dijelaskan bahwa kesalahan prosedur pada tahap processing sangat berpengaruh pada kualitas radiograf yang dihasilkan. Pada penelitian ini terlihat bahwa operator melakukan prosedur processing tidak sesuai dengan SOP. Kebanyakan kesalahan terlihat pada saat processing, dengan adanya penambahan atau pengurangan waktu processing dapat membuat kualitas radiograf, meliputi nilai kecerahan, kontras, detail dan ketajaman, menjadi kurang baik. ${ }^{3}$

Berdasarkan hasil uji beda yang dilakukan, dapatkan hasil $\rho=0,500$, berarti $\rho>\alpha(0,05)$ sehingga $\mathrm{H}_{1}$ ditolak yang artinya tidak ada perbedaan kualitas hasil radiograf periapikal film konvensional dan film instan pada mahasiswa profesi radiologi Fakultas Kedokteran Gig Universitas Brawijaya Malang. Nilai koefisien korelasi 0.000 artinya nilai hubungan sangat rendah dengan arah hubungan positif. Hal ini sejalan dengan penelitian oleh Bafagih yang dilakukan pada tahun 2017, menyebutkan bahwa kegagalan radiograf periapikal pada mahasiswa profesi kedokteran gigi di RSGM UMY yang paling banyak terjadi dari seluruh kegagalan adalah 91,3\% gambar film kabur atau buram yang berpengaruh terhadap kualitas radiograf, dalam penelitian tersebut film yang digunakan adalah film konvensional yang artinya film konvensional memiliki kualitas hasil radiograf yang kurang baik, meski hal tersebut berhubungan juga dengan kesalahan dalam tahap processing film. ${ }^{14}$

Kelebihan film konvensional adalah film lebih mudah didapat, gambaran lebih gelap dengan kontras detail sehingga ketajaman lebih baik dibandingkan film instan, bisa mengontrol kontras detail ketajaman dengan mengatur waktu developer dan fixer, ukuran panjang packing film konvensional lebih pendek kurang lebih 8 milimeter dari film instan sehingga lebih cocok untuk berbagai ukuran rahang dan tidak mengakibatkan perasaan tidak nyaman di rongga mulut bagi pasien. Kelebihan film instan adalah processing film lebih praktis karena tidak memakai kamar gelap dan tidak menjaga kualitas dari larutan developer dan fixer, lebih cepat untuk melihat hasil radiograf, menurut pandangan peneliti dari hasil film instan yang diperoleh meskipun gambaran lebih terang, kualitas hasil film stabil karena tidak menggunakan larutan developer dan fixer yang kualitasnya dipengaruhi seberapa banyak pemakaian larutan. Pada penelitian ini baik pada film konvensional dan film instan pada tahap processing sudah memenuhi standar operating procedure.

Penggunaan film instan lebih direkomendasikan untuk mengganti film periapikal konvensional dikarenakan memiliki beberapa keunggulan seperti dapat mengurangi kesalahan tahap processing dan kecepatan serta kepraktisan film. Tidak adanya perbedaan yang signifikan kualitas hasil periapikal film konvensional dan film instan disebabkan selama processing masing-masing film diarahkan sesuai standard operating procedure sehingga meminimalisir kesalahan dan memaksimalkan hasil film radiograf periapikal. Penelitian ini membuktikan bahwa kualitas hasil film konvensional dengan film instan tidak ada perbedaan, tetapi nampak ada ciri khas bahwa hasil film instan lebih terang dari pada film konvensional.

\section{SIMPULAN}

Bedasarkan hasil penelitian, terlihat ada sedikit perbedaan hasil antara metode processing dengan film konvensional dan film instan. Berdasarkan hal ini maka dapat disimpulkan bahwa tidak ada perbedaan kualitas hasil radiograf periapikal film konvensional dan film instan di Instalasi Radiologi Fakultas Kedokteran Gigi Universitas Brawijaya Malang.

\section{DAFTAR PUSTAKA}

1. Williamson G.F, Miles DA, Van Dis ML, et al. Radiographic Imaging for the Dental Team, 4th Ed. St. Louis, MO. Saunders. 2009:139-52

2. Hammo M. 2008. Tips for Endodontik Radiography. Smile Dental Journal; 2008; 3: p. 32-4

3. Whaites E, Drage N. 2013. Essentials of Dental Radiography and Radiology, Fifth Edition. London : Churchill Livingstone.

4. Ireland R. 2015. Kamus Kedokteran Gigi. Jakarta : EGC

5. Ishaq W. 2015. Tingkat Penggunaan Radiografi Periapikal Pada Dokter Gigi Praktek Di Kabupaten Maros Terhadap Perawatan Endodontik. Tugas Akhir. Tidak diterbitkan, Fakultas Kedokteran Gigi Universitas Hasanudin, 2015.

6. Masserat V Ebrahimi HS. Eil N. Mollashahi J Naebi M. 2017. Evaluation of Frequency of Periapical Radiographic errors in Dental Radiology Department in Zahedan in 2014-2015. Scholars Journal of Applied Medical Sciences (SJAMS), vol 1B, h 112-115.

7. Haghnegahdar A, Bronoosh P, Taheri M, Farjood A. Common intraoral radiographic errors made by dental students. GMJ 2013; 2; 44-8.

8. Peker I, Alkur M. T. 2009. Evaluation of radiographic errors made by undergraduate dental students in eriapical radiography. NYSDJ., 9:45-8.

9. Firman, R. 2003. Perkembangan dan Penggunaan Radiografi Dalam Bidang Kedokteran: Journal Of The Indonesian Dental Assosiation: 319-22.

10. White S.C, Pharoah M.J. 2009. Oral Radiology : Principles and Interpretation. Mosby : Elsevier

11. Whaites E. 2007. Essentials of Dental Radiography and Radiology, Fourth Edition. London: Churchill Livingstone.

12. Anil G. Ghom dan Savita A. Ghom. 2014. Text Book of Oral Medicine. New Delhi: Jaypee Brother Publisher.

13. Suryantoro, Rio. 2007. Perbedaan Detil Gambaran Radiografis Obyek Interdental Pada Model Gigi Menggunakan Film Instan Dengan Dan Tanpa Filter. Jakarta: Fakultas Kedokteran Gigi Universitas Indonesia.

14. Bafagih IAB. 2017. Persentase Jenis Kegagalan Radiograf Periapikal di RSGM UMY Yang Diterima Oleh Mahasiswa Profesi Kedokteran Gigi UMY Angkatan 2015. Tugas Akhir. Tidak diterbitkan, Fakultas Kedokteran dan IImu Kesehatan Universitas Muhamadiyah Yogyakarta, 2017. 